\title{
GOVERNMENTAL MECHANISMS FOR ADMINISTRATION OF MASS MEDIA IN RUSSIA'S NATIONAL REPUBLICS
}

\author{
Erdem Dagbayev \\ Doctor of Sociology, Professor, Department of Political \\ Studies and Sociology, Buryat State University. \\ Address: 178 Babushkin St., 670031 Ulan-Ude, Russian Federation. \\ E-mail: edagbaev@mail.ru
}

\section{Nadezda Aydaeva}

PhD, Associate Professor of Political Studies, Department

of Applied Linguistics and Communications, ESSTU.

Address: Eastern Siberia State University of Technology and Management.

Of. 460, 40B, b.15, Kluchevskaya St., 670013 Ulan-Ude, Russian Federation.

E-mail: aidanar@mail.ru

\begin{abstract}
The systems of public administration in the national republics have one significant difference when compared with other types of regional subjects ("oblast" or "kray") in the Russian Federation. These systems have governmental media (state media) founded by public authorities and these media outlets' assets are in the ownership of these authorities. It gives a certain originality to both the national republics' and Russia's administrative practices and mass media functioning. It is common for experts to criticize the national republics' public administrations for withdrawal from the libertarian model, but most often, this critical thinking does not clarify the reasons which could have looked "positive" from the libertarian perspective. These reasons are the major factor in making public authorities maintain state media.

The paper aims to synthesize the practice of governmental administration of mass media in the national republics and explicate the administration model by considering the example of Buryatia. The authors give their own definition to the concept of "state media"; identify public authorities' and mass media's interaction principles as well as institutional specifics of mass media's functioning in the national subjects of Russia. The authors argue that state media's functioning is justified. Being a political institution, state media experience a serious impact of various social factors including political, economic and legal ones. In the process of political management, their interference provides the mass media with a resource potential.

The state mass media in Buryatia is founded by its government and operates under the supervision of a special body in the Administration of the Head and the Government of the Republic of Buryatia. In practice, this body is an operator and manager of the mass media industry and it possesses all the resources it needs, including financial, to run the industry. All the state media outlets have been joined into "Buryaad Unen Publishing House", a state autonomous institution. It provides state services via the implementation of particular func-
\end{abstract}


tions. One of these functions is conducting the state politics and policy that is the consequence of the political forces ratio on the regional and federal levels. The other functions include legitimization of law, publicizing activities of public authorities, and preservation and development of the national language (the Buryat peoples' language). The latter state media function is of major importance in the national republics.

The research approach is an environmental sociological analysis studying the influence of various social factors which are making an impact on the choice of government mechanisms for administering state media. For analysis of various aspects of state mass media's transformation into a social subject of policy, the authors combine sociological with institutional and discourse research methods.

Keywords: mass media; state mass media; regional state mass media; national republic; a system of governmental (public) administration; institutional features.

Citation: Dagbayev, E. \& Aydaeva, N. (2016). Governmental mechanisms for administration of mass media in Russia's national republics. Public Administration Issues, no 5 (Special Issue, electronic edition), pp. 150-159 (in English).

$S^{t a t}$ tate mass media in Russia functions as the result of a unique mechanism of governmental and public administration that has no precedent in developed countries. In its turn, in addition to informing the public, state mass media also implements a number of functions, allowing it to solve a layer of issues, from national to political ones. This phenomenon can be found mainly in the national republics of present day Russia.

According to Article 22 of the Republic of Buryatia's Law "On the Government of the Republic of Buryatia" (O Pravitelstve, 1995) the government as the supreme executive body of the Republic of Buryatia is to implement the uniform state policy, including in the field of the relations between different ethnic groups in the region (mezhnatsionalniye otnosheniya). Within its authority, the government is to realize, provide and protect the rights and freedoms of a person and citizen. To implement the state information policy, the President (nowadays Head) of the Republic of Buryatia V. Nagovitsin founded, in 2007, the Information and Analyses Committee as a division of Buryatia President's and Government's Administration. According to the provision on the Committee (Polozhenie, 2007), it is to bear all the responsibility for the implementation of public policy in the information field via a number of obligations. It should be noted that besides ensuring that the President-Prime Minister of Buryatia adheres to the terms and conditions for fulfilment of his constitutional powers in the field of the state information policy, and giving publicity to the President's and Government's activities, the Committee must design and implement programs to develop and support the republic and its districts' periodicals, electronic mass media, publishing and polygraphs.

As outlined in the provision issued in 2008 (Polozhenie, 2008) the Committee, among the other functions, has to develop the means and ways for a quick information response to problematic situations; offer CEO candidates for media outlets; design state policy towards mass media and mass communications; and develop control systems covering expenditure of the allocated funds on mass media and mass communication development programs. 
These functions show that they have set the universal objectives to the Committee to implement simultaneously. Production of mass information goes hand in hand with the direct administration and management of a number of industries, including publishing and polygraphs. Thus, the Committee ceases to be a common governmental division but turns into a department having all the resources, including financial, to manage industries. As a result, the state mass media joined to the autonomous state institution, Buryaad Unen Publishing House, has become the institution providing state services. Functional uniqueness of the state media stretches far beyond its actual mass information functions, as it is related to conducting the state politics and policy that are a consequence of political forces ratio on the regional and federal levels. The other functions include legitimization of law, publicizing activities of public authorities and preservation and development of the national language (the Buryat peoples' language). The latter state media function is of major importance in the national republics.

From the perspective of the widely known "four theories of the press", there are four approaches to mass information. They are the authoritarian theory, its continuation - the Soviet communistic, and two approaches opposite to these, including the theory of social responsibility, which is a modification of the third, libertarian theory. The eldest of these is the authoritarian theory, having originated during the Renaissance. According to it, the press has to function in the direction of top to bottom. The theory considers the press as the state's servant responsible only before the authorities. It has defined an initial model for the majority of world's national press systems.

The Western press in general and the American in particular, were initially founded within a liberal society where the right for the search for truth is considered to be a natural and inherent right of an individual. Consequently, the press has to be a partner in the search for truth. At the same time, libertarianism has sputtered out within the liberal society, as the authors of "the four theories of the press" concept show (Peterson, Siebert, Schramm, 1998). As far back as the 1930-1940s it became obvious that it was becoming more and more difficult for the press to be a free market of ideas. It has increasingly been dependent on the monopolistic capital. In this situation, the freedom and independence of the press from power (in this case the power of the capital) could hardly be argued.

The theory of social responsibility has been developed as the continuation of and, at the same time, essentially different from the libertarian model of the press. It is based on a fundamental premise of society that the monopolistic position of the media and power oblige them to be socially responsible. It means they should see that all sections of society are fairly presented in the mass information sphere and that the public has information enough for making its own opinion.

The Soviet communistic theory of the press has been considered to be a variety or a continuation of an authoritarian model. In the late Renaissance society, the truth was to come from the spheres close to the power, but the communistic press needed to support the domination of the party. The difference between the Soviet model and the classical authoritarian one is that the Soviet press has not been privately owned but has been in the possession of the state. Therefore, matters of profit have not guided it. 
Certainly, from a current perspective this classical theory looks rather schematic as it a priori comes from a liberal premise that the state and society are absolute antipodes. The political system in itself does not guarantee a democratic character of any of its institutions. It is only a general mechanism, a political construction. D. Easton, a classical author of the system theory (1953), characterizes a political system as no more than a complex of interactions by means of which they distribute power resources within a society.

If the press is organizationally or politically related to the state, it is incorrect to consider it an apologist of the press' non-freedom. We argue a state, a municipality or any public structure as well as an individual must have equal rights for the foundation of mass media. Many years ago, G. Altshul (1984), one of the distinguished mass media researchers, attempted to enforce people to consider the myths about "the fourth power" in a new way. He argued that mass media throughout the history had been no more than a blind chronicler of the others' deeds. In the case of mass media's active role in political life, it had been an agent of these or those public forces.

It is certain the state mass media depend on dominating political groups and thus it should be considered a power institution. They communicate ideas and norms, being offered or having been already applied, on behalf of the state. In this sense mass media can be considered a governmental institution (in the USSR the state represented by the Communist party was the only and exclusive owner of the press). Therefore, it is fair under current conditions for Russia to have state media. The power on various levels, one way or another, continues to own the mass media or it has the resources to influence the information policy of the press.

In addition to the print media, nowadays the state has a controlling stake in ORT, the open joint stock TV company; exercises full control over VGTRK TV company and has a stake in NTV TV company. It means they control the all-Russian TV channels. In the Republic of Buryatia there is a single state TV company (the Buryatia State TV and Radio Broadcasting Company), a branch of VGTRK. Therefore, there is no regional government television.

Any mass media, whether it is television or a radio, print media or on the Internet needs a lot of financing. Therefore, there is a great probability that any private mass media will be guided and controlled either by large corporations or by small companies financing its activity. In many cases, this media is aimed at promoting private interests but not public ones. Nevertheless, they contribute to the major purpose of the mass media which is to help society in its search for truth and the solution of political and social problems by presenting opposing facts and opinions. The mass media also serve as the public instrument of control over the government and power structures of any country (Chetvertkov, 2012). In its turn, the government, as one of the actors in public sphere, also has the right to compete for the public's attention via its own mass media and present its vision and explanation of the truth.

Thus, the state media should be considered as a state organization, implementing the functions of public administration in an indirect form (because according to definition mass media is not a power authority). State mass media 
include, firstly, editions founded by the state; secondly, mass media receiving financial aid from the state in the form of the budgetary subsidies and allocations or other legal forms. Thirdly, organizations whose property organizationally and legally is in the state's ownership. For example, according to Article 3 of the Federal Law "On Autonomous institutions" (Ob avtonomnykh, 2013) the property of autonomous enterprises and other forms of organizations is assigned to them according to the right of operational management provided by the Civil Code of the Russian Federation. This means that the property being operated by an autonomous organization belongs to the Russian Federation, to the subject of the Russian Federation or to a municipality. We define state media as a periodic print edition, a web media, a TV channel, a radio channel, a TV program, a radio program, a video program, a film chronicle program and other forms of periodic distribution of mass information under a constant name, founded by the state and represented by its authorities in order to implement state functions and reach national objectives. As a rule, this mass media is under the control of the state and accountable to it, financed from the federal or regional budget and constantly using state property.

State print mass media is founded according to the Federal Law "On general principles of the organization of legislative (representative) and executive power bodies in the subjects of the Russian Federation" (On general, 1999). Article 26.3 grants the subjects of the Federation the right to establish print mass media to publish its regulations. The law has allowed assigning "Buryatia" and "Buryaad Unen" newspapers the status of official state republican print media and now they are a source of official publications of normative legal acts.

In the Republic of Buryatia, the state mass media were founded in the form of two state print periodic media outlets joint in one legal entity - a State unitary enterprise "Buryaad Unen" Publishing house. This merger happened on February 20, 2001. Before this date, both outlets had been independent legal entities existing in the form of public institutions. According to the current legislation, unitary enterprises are commercial organizations having a single founder. In the case under consideration, the founder was the Administration of President and the Government of the Republic of Buryatia (nowadays - Administration of the Head of the Republic of Buryatia and the Government of the Republic of Buryatia). All the property of the enterprise was under state ownership, and budgetary subsidies were the main source of financing.

Over time, the number of editions issued by the enterprise constantly increased. In 2006, the Publishing house joined the Buryat book-publishing house which was on the verge of bankruptcy. In 2009 the Soyel-kultura Publishing house joined; a publisher of two literary journals "Baikal" (in Russian) and "Baygal" (in the Buryat language). These were very significant editions not only for the Republic of Buryatia but also for the whole of Siberia as well as the Far East. Due to public financing, these journals received a new impetus for further development. In April 1, 2013, SUE Buryaad Unen Publishing House was transformed into the Public autonomous institution of the Republic of Buryatia, "Buryaad Unen" Publishing House. The legal status of the organization actually did not change. It preserved the key criteria of a state (public) enterprise 
as all the property of the publisher was still under state ownership, its activity was financed by the republican budget, and the founder was the Administration of the Head and the Government of the Republic of Buryatia. However, since that time the Publishing House has been obliged to follow the state task in issuing newspapers. The state task is a document accepted annually by the founder of the publishing house, identifying the major objectives of newspaper issue, the key requirements to the content of releases and the volume of publications needed. In particular, in 2013-2014, the state task included in its requirements to publish official information, information on activity of government bodies and officials of republican public authorities, and normative legal acts of the Republic of Buryatia.

The status of an autonomous establishment gives it considerable freedom in economic activity towards a legal entity. Besides obligatory materials set by the state task, media outlets can publish advertisements and other kinds of paid papers. There are no restrictions in this respect and state media are equal with private media in their placement. Nevertheless, as far as state media must publish first what they are ordered and second what sells well, the fight for advertisers is a great challenge to them. The public newspapers Buryatia and Buryaad Unen can barely compete with popular newspapers and magazine, because the circulations and popularity of the latter can be several times higher. For instance, the number of copies of each release of the New Buryatia newspaper reaches 50 thousand while the state newspaper Buryatia releases from 3 thousand to 10 thousand copies. In the search for other sources of financing, public mass media are trying to source more advertising and publish more paid articles and custom (biased) papers, but finances from the budget and income from subscriptions and advertising still do not cover production expenses. Therefore, budgetary subsidies continue to be the principal source of financing for the print media in Buryatia, which only aggravates their dependence on the state.

First, the state mass media has been designed to conduct political policy of the state, which is a consequence of the political forces ratio on the federal or regional levels. In the regions with a strong, centralized power, control over mass media is tougher. On the contrary, in the regions where the fight for power is highly competitive and there is a strong opposition, the antagonism of the groups is explicated in the fight for media space. Control is primarily exercised via financing, when participants of political processes pay (sometimes secretly) the media's operational costs, making it dependent. The other ways of setting control are building personal confidential relations with journalists, lobbying for the appointment of "close" persons to senior positions in media outlets. Thus, the competition of political groups make it necessary for state authorities to run their own media which can be considered a power institute as well and as such needs good operating (Dagbayev, 2004).

The theory identifies three types of interaction between mass media institutions and their founders (Prokhorov, 2011). These interaction types define the information policy of the media's editorial office. According to the first interaction type, a founder directly sets tasks editorial staff and thus a media acts as a political body. This type of relation mostly suits the state and party press. 
They exercise the second interaction type when an editorial staff founds a mass media edition and issues it. It is obvious that the independent mass media belongs to the second type. The third interaction type is explicated in the case when a founder pursues the aim of filling in a certain information niche and provides freedom to the staff in the manner of their achievement of the aim.

Print state media play a principal role in the legitimization of law. Since 2013, Buryaad Unen Publishing House has rendered state services publishing laws of the Republic of Buryatia, and regulations of executive authorities of the Republic of Buryatia in its newspapers. The official electronic site of the Government of RB (Organy, http://egov-buryatia.ru/) states the total amount of issue of "Buryatia" and "Buryaad Unen" newspapers in 2014 made 5564 strips, and 4173.7 of them published content related to the state task. The major parts of the content were Laws and regulations of public authorities of the Republic of Buryatia which made up $62.1 \%$ of the content or 2592 strips. In addition to the communication of regulations via print media, they also placed sections of normative documents on the pravo.gov.ru federal website and the official site of the Republic of Buryatia's Government. Thus, the state print media is of benefit to the Buryatian authorities as it helps to reduce difficulties in publicizing their public policy and introducing laws and regulations, whereas the other regional bodies are facing problems in this area as they lack their own media.

To reach a larger audience the Government involves non-governmental mass media. One of the involvement mechanisms is making contracts with media of various organizational and legal forms. In 2014, the Government signed 11 state contracts with the leading Buryatian TV channels, and 45 state contracts with republican and regional newspapers and news agencies. The total time on TV channels broadcasting about public authorities amounted to $2115 \mathrm{~min}$ utes. The total share of information materials on Buryatia's executive authorities made up $47.5 \%$ of the total newspaper sites, with $12 \%$ of republican print media and $35.5 \%$ of the regional one. In fact, the planned figure was exceeded, though it was less than the indicators of 2013. Reduced financing for information maintenance in 2014 caused the decrease. Nevertheless, as the Information and Analytical Committee states, the level of the audience's knowledge of executive bodies has increased as a result of their efficient media relations.

However, the primary social mission of the state press in the national republics is the preservation and development of the national language (the language of the minor or the title ethnic group of the republic). Nowadays, in all of the national republics there are print periodicals in the language of the title nations of these regions. For instance, the Republic of Tatarstan has the "Vatanym Tatarstan" newspaper, Khanty-Mansi Autonomous Area publishes "The Khanty Yasang", the Republic of Kalmykia issues "Halmg Unn", Buryatia prints the "Buryaad Unen" newspaper in the Buryat language, etc. In fact, nearly all of them are state editions, as the majority of the commercial press is not able to issue in the ethnic language, as they do not sell in large enough numbers.

Thus, by issuing mass media in the language of minorities, governments provide the rights that are fixed in the Constitution of the Russian Federation. In particular, Article 26 guarantees an individual's freedom in usage of his native 
language to communicate, educate, learn and create (Konstitutsia, 2003). In a multicultural society, mass media in the language of minorities contribute to federal public policy objectives: a) preservation and development of cultures and languages of the people of the Russian Federation, strengthening their spiritual unity and $b$ ) ensuring the rights of indigenous ethnic groups and ethnic minorities (O strategii, 2012).

Therefore, the governments of the national republics use legal norms to found state media in the languages of ethnic groups. The federal law "On the languages of the peoples of the Russian Federation" (O yazykakh, 1991) and the law of the Republic of Buryatia "On the languages of the peoples of the Republic of Buryatia" (O yazykakh, 1992) have developed the legal basis for issuing this media. The laws granted the subjects of the Russian Federation the right to adopt the languages of the indigenous people, living on their territories, as state languages. According to the law, Buryat along with Russian was legislatively recognized as the state language. Consequently, the government has received the right to found state media in the Buryat language. The "Buryaad Unen" newspaper performs the laws above publishing the content, which is common for mixed types of newspapers (including politics and policy, business, entertainment and advertising), but it is the only media, publishing normative legal acts of the Republic of Buryatia in the Buryat language. To translate them from Russian they spent 418.5 thousand rubles.

The other type of Government media relations for promoting the Buryat culture and language are electronic media relations. The mechanisms involve providing electronic auctions and making contracts on rendering services. For instance, in one of the auctions its participants have competed in the design and broadcast of conceptual TV programs in the Buryat language for children and the youth. The Buryatia TV and Radio Broadcast State Company has designed and has been broadcasting an entertaining and educating program. They have invited the best professionals that use advanced methods in teaching the Buryat language. Russia-24 and Russia 1 TV channels broadcast the Altan Naran program twice a week.

We argue that the legal and economic mechanisms of governmental interactions with mass media contribute to improving and increasing state services in the national republics, promoting legal and ethnic culture, and increasing information on public policy and knowledge on the activities of the public authorities. These mechanisms allow the involvement of private mass media in the promotion of the legal norms, mastering the native language and communicating public policy in an efficient way. State media play a special role being a major contributor to these processes. For further improvement of its functioning, we need to introduce new normative acts. These will border activities regarding state services and journalistic performance itself, that they will not be able to control politically. 


\section{REFERENCES}

1. Altshull, J.H. (1984). Agents of Power: the Role of the News Media in Human Affairs. New York and London: Longman.

2. Chetvertkov, N.V. (2012). Sotsialno-pravovye teorii pressy [Social and Legal Theories of the Press]. Izvestia vyschikh uchebnykh zavedeniy. Povolzhskiy region. Obschestvennnye nauki, no 3. p. 42.

3. Dagbayev, E.D. (2004). Sredstva massovoy informatsii: dinamicheskie modeli politicheskoy kommunikatsii [Mass Media: Dynamic Models of Political Communication]. Ulan-Ude: Buryat State University Publisher. 267 p.

4. Easton, D. (1953). The Political System: an Inquiry into the State of Political System. N.Y.: McGraw-Hill.

5. Konstitutsia Rossiyskoy Federatsii. (1993). [Constitution of the Russian Federation]. Available: http://www.consultant.ru/search/4 (accessed: 12 August, 2016).

6. O Pravitelstve Respubliki Buryatia [On the Government of the Republic of Buryatiya]: Law of the Republic of Buryatia, dated 21 June, 1995, no 140-1. Available: http:// docs.cntd.ru/document/939400746 (accessed: 10 September, 2016).

7. Ob avtonomnykh uchrezhdeniyakh [On Autonomous Institutions]: Federal Law, dated 3 November, 2006. N 174-FL (edited 28 December, 2013). Available: http:// www.consultant.ru/search/base/?q (accessed: 20 August, 2016).

8. Organy gosudarstvennoy vlasty Respubliki Buryatia [State Power Bodies of the Republic of Buryatia]: The official Internet portal. Available: http://egov-buryatia.ru/ (accessed: 13 September, 2016).

9. O strategii gosudarstvennoy natsionalnoy politiki Rossiyskoy Federatsii na period do 2025 goda [On the Strategy of the State National Policy of the Russian Federation for the Period to 2025: the Decree of President of the Russian Federation, dated 19 December, 2012, N 1666. Available: http://base.garant.ru/70284810/ (accessed: 10 September, 2016).

10. Ob obschikh printsipakh organizatsii zakonodatelnikh (predstavitelnikh) i ispolnitelnikh organov gosudarstvennoy vlasti subektov Rossiiskoy Federatsii [On General Principles of the Organization of Legislative (Representative) and Executive Power Bodies in the Subjects of the Russian Federation]. Federal Law dated 6 October, 1999, N 184-FL. Available: http://www.consultant.ru/cons/cgi/online. cgi?req=doc;base $=\mathrm{LAW} ; \mathrm{n}=200822$ (accessed: 12 September, 2016).

11. O yazykakh narodov Respubliki Buryatia [On the Languages of the Peoples of the Republic of Buryatia]: The Law of the Republic of Buryatia, dated 19 June, 1992, N 221-XII. Available: http://base.garant.ru/29500000/ (accessed: 30 August, 2016).

12. O yazykakh narodov Rossiyskoy Federatsii [On the Languages of the Peoples of the Russian Federation]: the Federeal Law dated 25 October, 1991 no 1807-1. Available: http://base.garant.ru/70284810/ (accessed: 25 August, 2016). 
13. Peterson, T., Siebert, F. \& Schramm, W. (1998). Chetire teorii pressy [Four Theories of the Press]. Moscow: Vagrius. 223 p.

14. Prokhorov, E.P. (2011). Vvedenie v teoriyu zhurnalistiki [Introduction into the Theory of Journalism]. Moscow: Aspect Press. 351 p.

15. Polozhenie ob Informatsionno-analiticheskom Komitete Administratsii Presidenta i Pravitelstva Respubliki Buryatia [Provision on Information and Analytical Committee of the President's Administration and the Government of the Republic of Buryatia]: The Decree of the President of the Republic of Buryatia, dated 25 December, 2007, n 741. Available: egov-buryatia.ru/fileadmin/iak/ДРОНД_2011_АПиП_ РБ.doc (accessed: 10 August, 2016).

16. Polozhenie ob Informatsionno-analiticheskom Komitete Administratsii Presidenta i Pravitelstva Respubliki Buryatia [Provision on Information and Analytical Committee of the President's Administration and the Government of the Republic of Buryatia] (2008): The Decree of the President of the Republic of Buryatia, dated 26 June, 2008, no 169. Available: egov-buryatia.ru/uploads/.../Проект_указа_ Администрация_Главы_РБ.do (accessed: 10 August, 2016). 